\title{
COMMENTARY
}

\section{Evolution by natural selection: more evidence than ever before}

\author{
Evolución por selección natural: más evidencias que nunca
}

\author{
ROBERTO F. NESPOLO \\ Instituto de Ecología y Evolución, Facultad de Ciencias, Universidad Austral de Chile. \\ Casilla 567, Valdivia, Chile; e-mail: robertonespolo@uach.cl
}

\begin{abstract}
The modern evolutionary theory, understood as the integration of the empirically-demonstrated theoretical foundations of organic evolution, is one of the most pervasive conceptual frameworks in biology. However, some debate has arisen in the Chilean scientific community regarding the legitimacy of natural selection as a mechanism that explains adaptive evolution. This review surveys the recent evidence for natural selection and its consequences on natural and artificial populations. In addition to the literature review, I present basic conceptual tools for the study of microevolution at the ecological scale, from a quantitative point of view. The outcome is clear: natural selection can be, is being, and has been quantified and demonstrated in both the field and in the laboratory, not many, but hundred of times during the past decades. The study of evolution by natural selection has attained maturity, which is demonstrated by the appearance of several syntheses and meta-analyses, as well as "evolutionary applications" where evolution by natural selection is used to resolve practical problems in disciplines other than pure biology. Caution is required when challenging evolutionary theory. The abundant evidence supporting this conceptual body demands a careful examination of available evidence before dogmatically critizing its theoretical foundations.
\end{abstract}

Key words: evolution, natural selection, adaptations, heritability, directional selection differential, artificial selection.

\section{RESUMEN}

La teoría moderna de la evolución, entendida como la integración del conocimiento teórico y empírico de la evolución orgánica, desarrollado desde Darwin hasta ahora, es uno de los cuerpos conceptuales más importantes en biología. Sin embargo, cierto debate ha surgido en el medio científico local en torno a la validez de la selección natural como mecanismo explicativo de la evolución adaptativa. Este artículo revisa las evidencias recientes sobre el rol de la selección natural en poblaciones naturales y artificiales. Además, se presentan algunas herramientas conceptuales básicas necesarias para el estudio de la microevolución a escala ecológica, las que se discuten a la luz de la información mostrada desde un punto de vista cuantitativo. El resultado es claro: la selección natural puede ser, está siendo y ha sido medida y demostrada en el campo y en el laboratorio, no muchas, sino cientos de veces durante las últimas décadas. El estudio de la evolución por selección natural ha alcanzado una fase de madurez que es demostrada por la aparición de varias síntesis y metaanálisis así como también por el comienzo de "aplicaciones evolutivas", donde la evolución por selección natural es utilizada para resolver problemas prácticos en disciplinas diferentes a la biologia básica. Se concluye que se necesita cautela cuando se cuestiona la teoría evolutiva. La gran cantidad de evidencia disponible exige un esfuerzo serio por leer y analizar dicho conocimiento antes de criticar sus fundamentos teóricos.

Palabras clave: evolución, selección natural, adaptaciones, heredabilidad, diferencial de selección direccional, selección artificial.

\section{INTRODUCTION}

In recent years there have been claims -in the daily press, on television, and by retired cosmologiststhat Darwin may have been wrong... However, to see Darwinism as being under serious threat would, I think, be a false perception.

John Maynard-Smith
The scientific method relies on skepticism, experiments and demonstration. To be accepted in the scientific community, new hypotheses must be based on strong proofs. Only then, the hypothesis becomes a theory. This is the way by which science progresses: upon a permanent and recursive self-validation (Sagan 1979, Levins \& Lewontin 1985). One of the most 
pervasive theories in biological sciences is modern evolutionary theory ${ }^{1}$, with natural selection as the main mechanism explaining adaptations (Williams 1966, Stenseth 1999, Gould 2002). However, as with other theories in biology, the modern theory of evolution is a conceptual body of knowledge that integrates several interdisciplinary fields. This modern synthesis has been developed during more than 150 years, from Darwin to the present, and integrates Mendelian genetics, systematics, paleontology, and ecology into a coherent theory of evolution. More recently, modern synthesis also combines the theory of natural selection with the emerging understanding of how genes are transmitted from one generation to another (Stenseth 1999). This framework involves verbal propositions, metaphors, mathematical models and statistical methods (e.g., Michod 1999, Gould 2002). Depending on the timeframe, spatial and organizational level of study, the analysis of evolution takes different approaches, although common features persist. The main mechanism of adaptive evolutionary change (sensu Williams 1966) is natural selection, which can act at different organizational levels (Lewontin 1970, Vrba \& Gould 1986, Nunney 1999, Weber 2000). In most cases, specially at the ecological time scale, the evidence suggests that the organism is the main unit of selection (Williams 1966, Maynard-Smith \& Price 1973). Hence, the raw material for selection is intraspecific variability (Fisher 1930, Haldane 1932, Wright 1988).

Felsenstein (1988) pointed out that: "Systematists and evolutionary geneticists don't often talk to each other, and they routinely disparage each other's work as being of little relevance to evolution. Systematists sometimes invoke the punctuationist argument that most evolutionary change does not occur by individual selection and hence that withinpopulation phenomena are largely irrelevant to evolution... Evolutionary geneticists in turn dismiss the idea that studies comparing species anciently diverged, using morphological

\footnotetext{
${ }^{1}$ This theory is understood as the integration of the empirically demonstrated theoretical knowledge of organic evolution developed from Darwin to present. I do not agree with the idea of a single "evolutionary theory" or theories that are mutually exclusive in explaining the same evolutionary processes as Manríquez \& Rothhammer presented it (1997, see the criticism by Camus 1997). Similarly, changes in the names and adjectives (e.g., "modern", "neodarwinian", "synthesis") used to describe this knowledge are a matter of preference, but it does not help to avoid jargon.
}

characters far removed from the level of the gene and using nonquantitative methods, can either be sound in their inferences of pattern or can shed much light on evolutionary processes". Although this is a caricaturized view of two different schools in evolutionary biology (i.e., systematics versus evolutionary genetics), some of this confrontation is present in the Chilean style of teaching evolution where, I believe, the former (systematics) approach prevails.

There is a long tradition of evolutionary thinking in Chile (Manríquez \& Rotthammer 1997), however, undergraduate courses of evolution have been markedly biased to favor the systematic-taxonomical and historical view of evolution (Camus 1997, Manríquez \& Rotthammer 1997). Popular topics in courses of evolution are the vitalism-evolutionist debate, the origin of life on Earth, biogeography, phylogenetics and comparative methods, and phyletic gradualism versus saltationism. This may provide an adequate picture of the history of systematic evolutionary thought, but it is not a realistic picture of current research in evolutionary biology. In these evolution classes, natural selection -the mechanism of adaptive evolutionary change-, and the analysis of variation -the raw material for natural selection- are usually mentioned directly from Darwin words or anecdotic and qualitative examples ${ }^{2}$. These concepts are not taught along with the well-established quantitative tools developed to measure them. In short, the proofs for natural selection or evolution itself are usually not teached in Chilean undergraduate courses. As a consequence, it is common to hear comments such as "...nobody can prove evolution..." or "...it is impossible to measure natural selection..." in classrooms, and even in scientific meetings ${ }^{2,3}$. Moreover, one may see publications in local scientific media, which give naïve and qualitative examples, such as birds feeding in suboptimal food patches, to claim that evolutionary theory is obsolete because it does not explain such apparently non-adaptive behavior (Marone et al. 2002). Worse yet, some biologists appear to recall past and expired controversies, such as the obsolete dogma "one gene, one trait" as actual limitations to evolutionary theory (Maturana \& Mpodozis 2000). In short, any course of

\footnotetext{
${ }^{2}$ Direct experience of the author in undergraduate courses at P. Universidad Católica de Chile and Universidad de Chile from 1995 to 2000 .

${ }^{3}$ Reunión conjunta de las sociedades de ecología de Argentina y Chile, see also Marone et al. (2002).
} 
evolution should take care of the whole body of theoretical and empirical knowledge accumulated during the last 150 years, and it may include some less well known mechanisms as long as some minimum evidence supports them.

There is a general problem of ignorance of science and especially regarding the facts of evolution. Many people, including scientists and the lay public, are unaware of the relevancy of evolutionary biology. Furthermore, the attacks to supress the teaching of evolution have received widespread support at the local level in the USA (Antolin \& Herbers 2001, Bull \& Whichman 2001). This is just a consequence of a crisis which is affecting evolutionary biology and is evidenced in simple facts. For example, $35 \%$ of American college graduates think that "the earliest humans lived at the same time as dinosaurs" and $42 \%$ indicated that they did not think "human beings, as we know them today, developed from earlier species of humans" (Alters \& Nelson 2002). These authors suggest that such ignorance follows from deficient methods of undergraduate teaching.

What the last paragraph, regarding missconceptions of evolution facts in the USA, has to do with former discussions about the Chilean teaching of evolution? I believe both are epiphenomena of the same general problem: incorrect teaching of evolution. For example, it is not surprising to find out that both graduate and undergraduate Chilean students of ecology and evolution believe that evolution cannot be tested experimentally ${ }^{2}$. Moreover, some biologists strongly believe that natural selection is not a mechanism that explain adaptations (Maturana \& Mpodozis 2000, Marone et al. 2002). In fact, some of them proposed a new evolutionary theory, the so-called "natural drift" (Maturana \& Mpodozis 1992, 2000), which in part, stimulated this commentary.

Among other arguments, Maturana \& Mpodozis (2000) claim that modern evolutionary theory fails to explain adaptations, or that it has been misinterpreted. Unfortunately, the work of Maturana \& Mpodozis (2000) is weak in at least three basic aspects of any new hypothesis. First, the poor and tautological writing makes it hard to follow, a point that has been criticized in detail elsewhere (Gallardo 1997, Manríquez \& Rothhammer 1997). Second, it ignores at least 30 years of ecological-evolutionary research, which explains why they find so many facts that modern evolutionary theory cannot account for (e.g., non-adaptive traits, constraints to evolution, neutral change). These criticisms are mentioned by Gallardo (1997) and Manríquez \& Rothhammer (1997), but mostly from the systematic perspective. Third, in nearly 50 pages (and 28 references, six of which are self citations), they do not present a single case that supports the natural drift (Maturana \& Mpodozis 2000). This last point has not been discussed in detail before. Obviously, empirical evidence is the most important structural support for any hypothesis that is posed to become a theory.

This review is directed to students and young biologists in Chile, and was motivated by the general problem of a lack of knowledge about evolution, and the challenge placed by Maturana \& Mpodozis (2000) to modern evolutionary theory. In science all new ideas must be open to debate. However, students of science need to be presented with proofs of what they are learning. Many new ideas are interesting and appealing, but if not subjected to verification by systematic research, they are no longer scientific and become dogmatic (e.g., Fischer 2001, see review in Gallardo 2001). Dogmas are dangerous when taught as truths. Even worse, teaching that a well established theory, such as evolution by natural selection, is simply wrong (Antolin \& Herbers 2001), as it occurs in Chile (Maturana \& Mpodozis 2000), could have devastating consequences in the formation of new scientists.

Here, I offer a short, representative review of the recent evidence for natural selection from the perspective of quantitative genetics and phenotypic selection. In this review I defend that (1) a conceptual framework to study evolution experimentally does exist; (2) that natural selection is the main force of adaptive change in natural populations, and that (3) both natural selection and evolution can be, are being and have been measured and demonstrated both in the field and in the laboratory, not a few times, but hundreds of times during the past decades.

\section{CONCEPTUAL FRAMEWORK}

Three critical elements must be kept in mind when studying evolution by natural selection: (i) that a trait exhibits intraspecific variation, (ii) that this variation is heritable, and (iii) that the trait is the target of natural selection. To characterize these processes, some formalizations are needed.

In a large enough population, a metric trait is distributed in a continuous fashion. These kinds of traits are usually codified by several genes of small effects (Roff 1997). Assuming 
that natural (or sexual) selection acts directionally over this trait (Fig. 1A), there will be a number of individuals surviving the selective event. The important point here is that this process modifies both the variance and the mean of the distribution. Both effects have profound consequences to the population: the mean is changed by a value, " $S$ ", and the variance is reduced. In the next generation, the offspring of selected individuals will present the changed mean only if resemblance in the trait exists between parents and offspring.

Formally, $\mathrm{S}$ is defined as the selection differential, such that:

$\mathrm{S}=\mu-\mu_{\mathrm{o}}$

where $\mu_{\mathrm{o}}$ and $\mu$ are the population means before and after selection, respectively (Fig. 1A). If the trait is completely inherited, $\mu_{1}$, the population
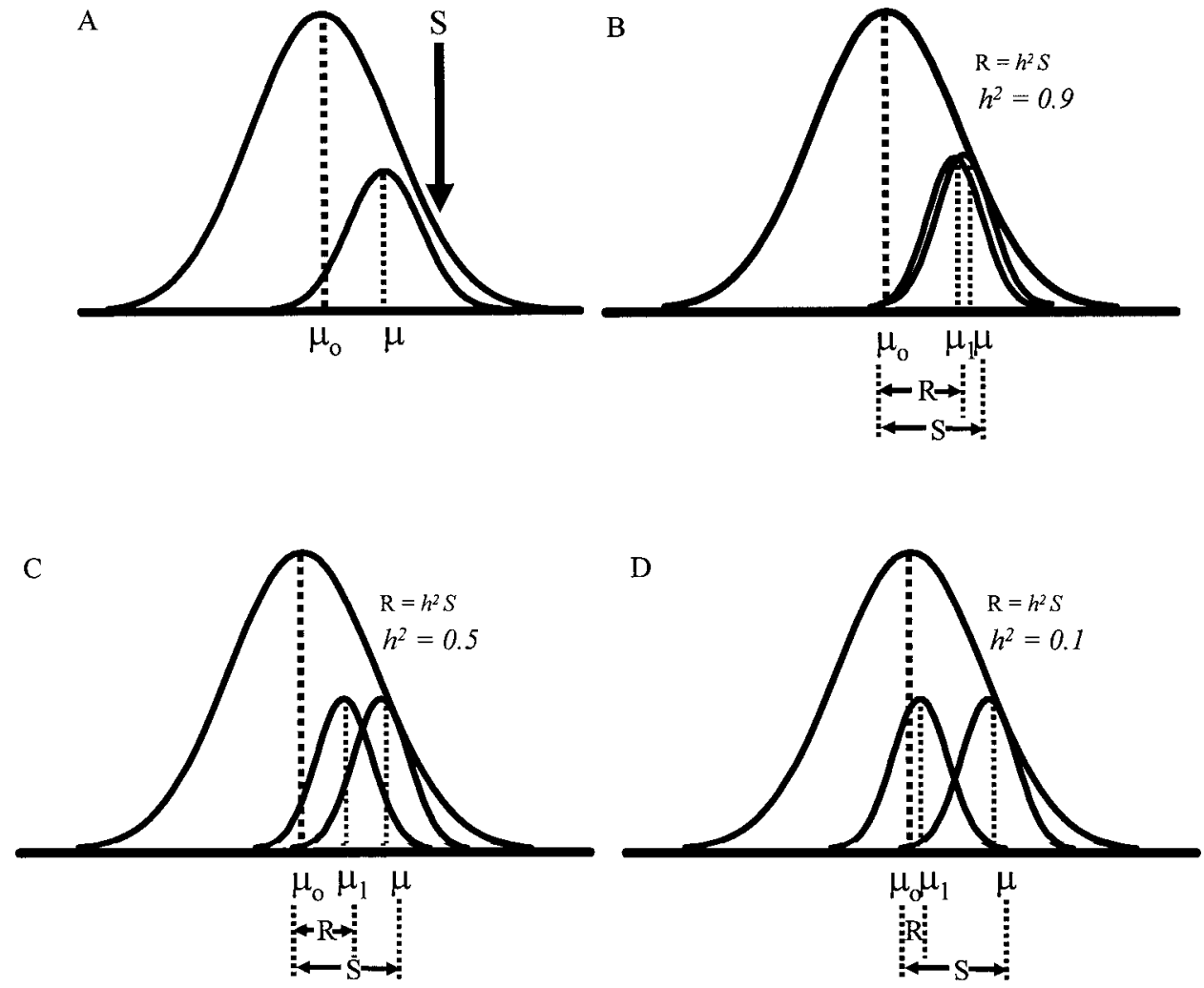

Fig. 1: (A) Directional selection acting on the right tail of a distribution of a metric trait in a large population. Large and small curves represent the distribution of the trait before and after selection. Similarly, $\mu_{\mathrm{o}}$ and $\mu$ represent the mean populational values before and after selection. (B) Directional selection differential $(S)$ and response to selection $(R)$ in a hypotetical trait with narrow-sense heritability $\left(\mathrm{h}^{2}\right)$ close to one. The mean populational values before and after selection are represented as $\mu_{\mathrm{o}}$ and $\mu$, respectively. The mean of the trait in the descendents of the selected individuals is $\mu_{1}$. (C) Directional selection differential (S) and response to selection (R) in a hypothetical trait with narrow-sense heritability $\left(\mathrm{h}^{2}\right)$ of intermediate value. (D) Directional selection differential (S) and response to selection $(\mathrm{R})$ in a hypothetical trait with narrow-sense heritability $\left(\mathrm{h}^{2}\right)$ close to zero.

(A) Selección direccional actuando en la cola derecha de la distribución de un rasgo métrico en una gran población. Las curvas grandes y pequeñas representan la distribución del rasgo antes y después de la selección. Similarmente, $\mu_{\mathrm{o}} \mathrm{y} \mu$ representan las medias poblacionales antes y después de la selección. (B) Diferencial de selección direccional (S) y respuesta a la selección $(R)$ en un rasgo hipotético con heredabilidad en sentido estricto ( ${ }^{2}$ ) cercana a uno. La media poblacional antes y después de la selección son representadas como $\mu_{\mathrm{o}} \mathrm{y} \mu$, respectivamente. La media poblacional del rasgo en los descendientes de los individuos seleccionados es $\mu_{1}$. (C) Diferencial de selección direccional (S) y respuesta a la selección (R) en un rasgo hipotético con heredabilidad en sentido estricto ( $\mathrm{h}^{2}$ ) de valor intermedio. (D) Diferencial de selección direccional $(\mathrm{S})$ y respuesta a la selección $(\mathrm{R})$ en un rasgo hipotético con heredabilidad en sentido estricto (h2) cercana a cero. 
mean of the offspring of selected individuals will be close to $\mu$ (Fig. 1B). On the contrary, a trait for which the genetic contribution is too low (i.e., only environmentally determined) will have a $\mu_{1}$ very close to $\mu_{\mathrm{o}}$ (Fig. 1D). This measure is called the narrow-sense heritability $\left(h^{2}\right)\left(0 \leq h^{2} \leq 1\right)$.

Hence, if $\mathrm{h}^{2} \approx 1$, then $\mu_{1} \approx \mu$; similarly if $\mathrm{h}^{2} \approx 0, \mu_{1} \approx \mu_{\mathrm{o}}$ (see Fig. 1B, 1C, and 1D). Narrow-sense heritability indicates the relative proportion of additive genetic variance to phenotypic variance. Additivity of gene effects relates to the fact that each gene is inherited individually. In evolutionary terms, the important fact is the individual contribution of each gene to the phenotype. Effects that depend on the interaction among genes (e.g., dominance, epistasis) are less important in the long term (and in large, panmitic populations) because these are properties of genotypes, not of genes. The additive genetic variance $\left(\mathrm{V}_{\mathrm{A}}\right)$ contains the variance of breeding values which are those properties of individual genes. Together, $\mathrm{V}_{\mathrm{A}}$ and $\mathrm{V}_{\mathrm{P}}$ make up $\mathrm{h}^{2}$ :

$\mathrm{h}^{2}=\mathrm{V}_{\mathrm{A}} / \mathrm{V}_{\mathrm{P}}$

Phenotypic variance $(\mathrm{Vp})$ becomes

$\mathrm{V}_{\mathrm{P}}=\mathrm{V}_{\mathrm{A}}+\mathrm{V}_{\mathrm{D}}+\mathrm{V}_{\mathrm{I}}+\mathrm{V}_{\mathrm{E}}$

where $\mathrm{V}_{\mathrm{D}}=$ dominance variance, $\mathrm{V}_{\mathrm{I}}=$ variance from interaction among loci (epistasis) and $\mathrm{V}_{\mathrm{E}}=$ environmental variance. Variance components can be visualized graphically as in Fig. 2, where $\mathrm{V}_{\mathrm{A}}$ is usually a small fraction of $\mathrm{V}_{\mathrm{P}}$.

From equation (1), and considering the introduced notation, it is possible to establish a measure of evolutionary change. We define $\mathrm{S}$ as the selection differential that measures the strength of natural selection, $\mathrm{R}$ is the difference between the mean trait value of the offspring of the selected individuals $\left(\mu_{1}\right)$ and the mean before selection $(\mu) ; R=\mu-\mu_{1}$ (Fig. 1B, 1C, 1D).

$\mathrm{R}=\mathrm{h}^{2} \mathrm{~S}$

Equation (4), known as the "breeders equation", shows that natural selection translates into evolution only if there is some degree of inheritance in the selected trait. The breeders equation has been empirically demonstrated and its components in many cases are different from zero (i.e., evolution by natural selection is occuring) (Falconer \& Mackay 1997). Two of the most important advances in evolutionary theory are the Fundamental Theorem of Natural Selection (Fisher 1930) and the Robertson-Price Identity

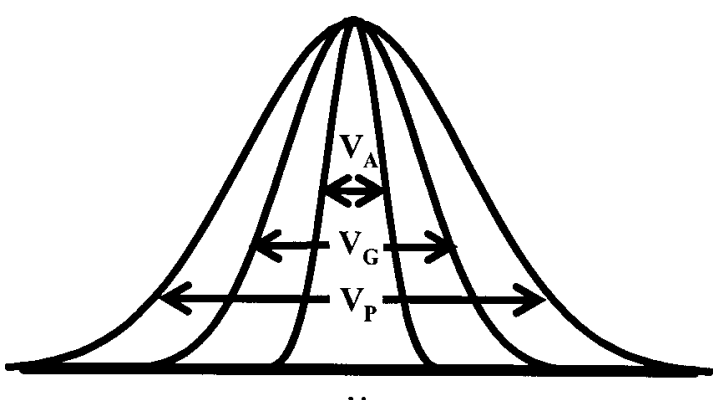

$\mu$

Fig. 2: Diagramatic representation of components of variance in a hypothetic trait (and a large population) with mean $\mu$ and variance $V_{P}$. Additive genetic variance $\left(\mathrm{V}_{\mathrm{A}}\right)$ accounts for variation in breeding values and, hence, is included as a small proportion of the genotypic variance $\left(\mathrm{V}_{\mathrm{G}}\right)$. The areas representing variance components are only for diagramatic purposes and cannot be taken as quantitative representations since variances are squared deviations (which technically cannot be represented diagramatically).

Representación esquemática de los componentes de varianza en un rasgo hipotético (y una población grande) con media $\mu$ y varianza $V_{P}$. La varianza genética aditiva $\left(V_{A}\right)$ da cuenta de la variación en los valores de cría y, por lo tanto, está incluida como una pequeña proporción de la varianza genotípica $\left(\mathrm{V}_{\mathrm{G}}\right)$. Las áreas representando los componentes de varianza son solo para propósitos diagramáticos y no pueden ser consideradas como representaciones cuantitativas dado que una varianza es una desviación al cuadrado (que técnicamente no puede ser representada diagramáticamente).

(Robertson 1966, Price 1970), also referred as the Secondary Theorem of Natural Selection (Caswell 1989) ${ }^{4}$. The important contributions of these models are that $\mathrm{S}$ can be equated to the covariance between a trait of interest $(\mathrm{z})$, and to relative fitness (w) (see Appendix),

$\mathrm{S}=\operatorname{Cov}(\mathrm{z}, \mathrm{w})$

The usefulness of this equation is clear from the fact that it is not necessary to measure the trait before and after natural selection, which can be very difficult, especially when selection occurs continuously over time and with overlapping generations. Equation (5) indicates that it is sufficient to measure the trait in each individual, along with a measure of the reproductive contribution of individuals to the

\footnotetext{
4 Actually, the Robertson-Price Identity is more general than the Fundamental Theorem since the latter can be derivated from the former (see Appendix 1).
} 
population, and to standardize these measures according to the average contribution of the total population (e.g., the mean number of offspring that attain sexual maturity). This univariate reasoning was extended to multiple traits and multivariate selection by Lande \& Arnold (1983, see also Arnold 1983, 1988). When multivariate selection and inheritance are considered, $\mathrm{h}^{2}$ is transformed into an additive genetic variance-covariance matrix (the $G$ matrix, which includes genetic correlations among traits), $S$ is changed into a vector of partial selection coefficients, termed the directional selection gradient (the B vector), and $\mathrm{R}$ is transformed into a vector of partial responses to selection (the $\Delta \mathbf{z}$ vector). Although it is not necessary to repeat this derivation here, it is enough to make the point that $\mathbf{G}, \boldsymbol{B}$ and $\Delta \mathbf{z}$ are equivalent to $\mathrm{h}^{2}, \mathrm{~S}$ and $\mathrm{R}$, respectively, when dealing with several traits (Lande \& Arnold 1983).

I found that at least ninety studies carried out during the last five years demonstrate the existence of strong selection differentials, high heritabilities, differential fitness and/or large responses to selection in natural and artificial populations of living organisms. Any person who is not convinced of the evidence that natural selection as an adaptive evolutionary agent, should analyze and criticize, in detail, each of these studies, not to mention the intensive research done and published by paleontolists, population geneticists and ecologists during last century after Darwin (see Haldane 1932, Provine 1985).

\section{DISCUSSION}

Natural selection, artificial selection and quantitative genetics

The evidence for natural selection is neither new nor scarce (Hoekstra et al. 2001, Kingsolver et al. 2001). In fact, Haldane in 1932 mentioned at least ten cases of phenotypic divergence due to natural selection in both wild and domestic species of plants and animals. Other known examples of early measurements of natural selection include the storm sparrows of Bumpus, and the industrial melanism of Kettlewell (Bumpus 1899, Kettlewell 1955, Grant 1999). More recently, several syntheses, reviews and meta-analyses have been published that include hundreds of studies dealing with heritability, natural selection, artificial selection and experimental evolution in both, artificial and natural settings (Endler 1986, Roff \& Mousseau
1986, Brodie et al. 1995, Roff 1997, Gibbs 1999, Conner 2001, Fairbairn \& Reeve 2001, Hoekstra et al. 2001, Kingsolver et al. 2001, Reznick \& Travis 2001, Stirling et al. 2002).

Classical works such as those by Haldane (1932), Endler (1986) and Lande \& Arnold (1983) have shown how natural selection can be measured in the field via a number of procedures. Statistical methodologies to determine natural selection dealing mostly with correlational statistics and fitness surfaces that make use of the Robertson-Price identity (equation 5, Appendix 1) have received a thorough analysis elsewhere (Lande \& Arnold 1983, Brodie et al. 1995, Fairbain \& Reeve 2001, Reznick \& Travis 2001, Appendix 1). A summary of recent evidences of natural selection using these applications is shown in Table 1, along with studies where the evidence of natural selection has been detected from mapping molecular structures and then inferring periods of adaptive change (Chen et al. 2000, Grossman et al. 2001). These studies are restricted to taxa where individuals are available in large numbers and amenable to experimental manipulation (e.g., flies, birds, humans, plants, reptiles, fishes and small mammals, see Table 1). The traits studied are similarly biased, with researchers focusing on either easy-to-measure traits (e.g., morphology) or survival-related traits (e.g., life histories) (Table 1, see also Hoekstra et al. 2001). However, natural or sexual selection can only be measured when significant variation in a trait can be detected. Since populations and organisms have existed during long time periods before present day, and since selection reduces genetic variation (see Appendix 1), the measurability of current natural selection should be low. In fact, the meta-analysis by Kingsolver et al. (2001) shows that the power of directional selection analyses is rather low, which means that a sample size below 135 individuals will yield poor estimates of selection differentials or gradients. Strong directional selection is not common in natural populations either, as compared with sexual selection (Hoekstra et al. 2001, Kingsolver et al. 2001). Despite these limitations, it is notable that natural selection can indeed be measured and demonstrated.

Quantitative genetic studies that account for the existence of additive genetic variance or narrow-sense heritability are quite common, probably more so than any other kind of evidence (Table 2). This is due, in part, to historical reasons: domestic animal and plant breeding programs began long before 


\section{TABLE 1}

Recent studies of natural or sexual selection measured in natural populations of living organisms. Natural selection was assessed by estimating the directional selection differential (S)

(or the selection gradient if multiple traits) in a cross-sectional study (see equation 1), unless stated otherwise. Molecular reconstruction means that the trait was mapped along with molecular data, and then the period of adaptive change was inferred from this information in the selected lineage. Indirect evidence is stated when historical information, along with correlational evidence, strongly suggest (but does not demonstrate) that natural selection is the main source of evolutionary change

Estudios recientes sobre selección sexual o natural, medidas en poblaciones naturales de organismos vivientes. Cuando no se especifique lo contrario, la selección natural se determinó a través del diferencial de selección direccional (S) (o el gradiente en el caso de múltiples rasgos) en un estudio transversal (ecuación 1). La reconstruccion molecular significa que el rasgo fue mapeado junto con caracteres moleculares, y un período de cambio adaptativo fue inferido a partir de esta información en el lineaje seleccionado. Se indica evidencia indirecta cuando la información histórica junto a la evidencia correlacional sugieren (pero no demuestran) a la selección natural como la principal fuente de cambio evolutivo

\begin{tabular}{|c|c|c|}
\hline Organism & Trait & Reference \\
\hline Red deer (Mammalia) & Body size & Schmidt \& Hoi (2002) \\
\hline Marine snail (Gastropoda) & Shell coloration & Parsonage \& Hughes (2002) \\
\hline Fruitfly (Insecta) & Codon bias (molecular reconstruction) & Hey \& Kliman (2002) \\
\hline Collared flycatcher (Aves) & Body condition and body mass & Merila et al. (2001a) \\
\hline Human (Mammalia) & Fascial paedomorphosis & Wehr et al. (2001) \\
\hline Teleost fish (Actinopterygii) & Triphosphate isomerase (molecular reconstruction) & Merritt \& Quattro (2001) \\
\hline Marine snake (Reptilia) & Morphology related with mate recognition & Shine \& Shetty (2001) \\
\hline Human male (Mammalia) & Height (measuring fitness) & Mueller \& Mazur (2001) \\
\hline Human female (Mammalia) & Life histories (measuring fitness) & Kirk et al. (2001) \\
\hline Human (Mammalia) & Aerobic metabolism leading to encephalic enlargement & Grossman et al. (2001) \\
\hline Atlantic cod (Actinopterygii) & Pantophysin I locus (molecular reconstruction) & Pogson (2001) \\
\hline Seed beetle (Insecta) & Egg size & Fox $(2000)$ \\
\hline Freshwater turtle (Reptilia) & Body size & Bodie \& Semlitsch (2000) \\
\hline Gecko (Reptilia) & Morphology (molecular reconstruction) & Gubitz et al. (2000) \\
\hline Marine bird (Aves) & Morphology relarted with mate recognition (indirect evidence) & Szekely et al. (2000) \\
\hline Lizard (Reptilia) & Life histories (measuring fitness) & Sinervo \& Zamudio (2001) \\
\hline Fern (Halophita) & External morphology(indirect evidence) & Kentner \& Mesler (2000) \\
\hline Domestic rat (Mammalia) & Resistence to poison (molecular reconstruction) & Kohn et al. (2000) \\
\hline Angiosperm & Sexual structures & Parra-Tabla \& Bullock (2000) \\
\hline Fruitfly (Insecta) & Genome region (molecular reconstruction) & Chen et al. (2000) \\
\hline Cliff swallow (Aves) & Morphology & Price et al. (2000) \\
\hline Angiosperm & Tolerance to herbivory & Juenger et al. (2000) \\
\hline Passerine Bird (Aves) & Morphology relarted with mate recognition & Balmford et al. (2000) \\
\hline Passerine Bird (Aves) & Arrival date for reproduction & Brown \& Brown (2000) \\
\hline Lizard (Reptilia) & External morphology (molecular reconstruction) & Malhotra \& Thorpe (2000) \\
\hline Angiosperm & Floration date (measuring fitness) & Kelly \& Levin (2000) \\
\hline Angiosperm & Floral phenology & Pilson (2000) \\
\hline Lizard (Reptilia) & Egg size and density-dependent selection & Svensson \& Sinervo (2000) \\
\hline Giant petrel (Aves) & Body size & Barbraud (2000) \\
\hline Columnar Cactus (Angiosperm) & Resistance to parasitism & Medel (2000) \\
\hline Lizard (Reptilia) & Male throat coloration (in relation to sexual selection) & Sinervo \& Zamudio (2001) \\
\hline Deer mouse (Mammalia) & Maximum aerobic metabolism & Hayes \& O’Connor (1999) \\
\hline
\end{tabular}




\section{TABLE 2}

Quantitative genetic studies that demonstrate the existence of additive genetic variation or narrow-sense heritability $\left(\mathrm{h}^{2}\right)$ in natural populations of organisms, and that suggest a potential for evolutionary change on these organisms and traits.

Authors that report both natural selection and additive genetic variance are presented in Table 1 as well

Estudios genético-cuantitativos que demuestran la existencia de variación genética aditiva o heredabilidad en sentido estricto $\left(\mathrm{h}^{2}\right)$ en poblaciones naturales de organismos, sugiriendo potencial para el cambio evolutivo en estos organismos y rasgos. Los autores que reportan selección natural y variación genética aditiva se presentan en la Tabla 1 también

\begin{tabular}{|c|c|c|}
\hline Organism & Trait & Reference \\
\hline Cricket (Insecta) & Sperm length & Keller et al. (2001) \\
\hline Wild mouse (Mammalia) & Life span & Klebanov et al. (2001) \\
\hline Marine snail (Gastropoda) & Shell size & Carballo et al. (2001) \\
\hline Frog (Amphibia) & Life histories & Watkins (2001) \\
\hline Darwin' finch (Aves) & External morphology & Ryan (2001) \\
\hline Teleost fish (Actinopterygii) & Secondary sexual characters & Karino \& Haijima (2001) \\
\hline Lizard (Reptilia) & Territoriality (related with sexual selection) & Sinervo \& Zamudio (2001) \\
\hline Passerine bird (Aves) & Migratory behavior & Pulido et al. (2001) \\
\hline Butterfly (Insecta) & Morphological & Saccheri et al. (2001) \\
\hline Bird (Aves) & Migratory behavior & Moller (2001) \\
\hline Daphnia (Crustacea) & Life histories & Pfrender \& Lynch (2000) \\
\hline Passerine bird (Aves) & Offspring solicitation (behavioral) & Kolliker et al. (2000) \\
\hline Passerine bird (Aves) & Body condition and body mass & Gosler \& Harper (2000) \\
\hline Wild sheep (Mammalia) & Life histories & Reale \& Festa-Bianchet (2000) \\
\hline Cricket (Insecta) & Life histories & Roff \& Bradford (2000) \\
\hline Weed (Angiosperm) & Life histories & Motten \& Stone (2000) \\
\hline Leaf beetle (Insecta) & Performance in host exploitation & Ballabeni \& Rahier (2000) \\
\hline Passerine bird (Aves) & Fledging body mass & Merila et al. (2001a) \\
\hline Passerine bird (Aves) & Body condition and body mass & Merila et al. (2001b) \\
\hline Human female (Mammalia) & Life histories & Kirk et al. (2001) \\
\hline Angiosperm & Tolerance to herbivory & Juenger \& Bergelson (2000) \\
\hline Blue fox (Mammalia) & Tolerance to human presence (behavioral) & Kenttamies et al. (2002) \\
\hline Fruitflie (Insecta) & Body size & Gockel et al. (2002) \\
\hline Suedish common Frog (Amphibia) & Larval growth & Uller et al. (2002) \\
\hline Caterpillar (Insecta) & Inmune function & Cotter \& Wilson (2002) \\
\hline Colias butterfly (Insecta) & Wing cryptic coloration & Ellers \& Boggs (2002) \\
\hline Guppy (Actinopterygii) & Mate selection behavior & Brooks \& Endler (2001a) \\
\hline Guppy (Actinopterygii) & Male ornaments & Brooks \& Endler (2001b) \\
\hline Great Tit (Aves) & Laying date & Van der Jeud \& McCleery (2002) \\
\hline Dung fly (Insecta) & External morphology & Blanckenhorn (2002) \\
\hline Common bee (Insecta) & External morphology & Monteiro et al. (2002) \\
\hline Human (Mammalia) & Aerobic capacity and explosive power & Calvo et al. (2002) \\
\hline Medicinal leech (Annelida) & Reproductive traits & Utevskaya \& Atramentova (2002) \\
\hline
\end{tabular}


evolutionary studies (Haldane 1932, Falconer \& Mackay 1997, Roff 1997, Lynch \& Walsh 1998). Additionally, quantitative genetic analyses can be done in experimental settings, which makes easier such research. From Table 2 , it is clear that birds, insects, fishes and plants are the preferred models for measuring $h^{2}$ in wild populations. As seen in natural selection studies, easy-to-measure traits in the laboratory also are the norm in studies of heritability (morphology, behavior and life histories). Yet low statistical power (i.e., large sample size is needed) is also a common problem of these studies. In quantitative genetic analyses the null hypothesis is that $h^{2}=0$. Hence, when the real value of $h^{2}$ is near to zero (e.g., as in life history, behavioral and physiological traits, see Roff 1997), hundreds or even thousands, of data records (individuals) are needed to demonstrate significant heritabilities. Physiological traits are a especially dramatic case since these traits are difficult to measure, and generally exhibit low values of $\mathrm{h}^{2}$ (Tsuji et al. 1989, Hoffman 2000, Dohm et al. 2001, Nespolo et al. 2003). In spite of these limitations, hundreds of high values of $\mathrm{h}^{2}$ have been reported to date (see Table 2 and references therein).

A fourth line of evidence that supports the occurrence of natural selection comes from artifical selection experiments (Table 3) where the researcher selects the parental individuals that will produce the next generation according to their extreme phenotypes (i.e., the researcher acts as the selection differential). Since $S$ is known (imposed by the experimenter) the rate of evolution can be estimated directly from $\mathrm{R}$ and $\mathrm{h}^{2}$, now called "realized heritability", is computed after solving equation (4) (Gibbs 1999). In contrast to artificial selection, studies of experimental evolution (Table 4) allow laboratory populations to evolve in an specific environment (Gibbs 1999, Stearns et al. 2000). These experiments have provided spectacular evidence for evolution, since the population

TABLE 3

Artificial selection studies. A significant change in the mean phenotype is induced over several generations in organisms subjected to a strong imposed selection.

The researcher actively selects individuals with the extreme phenotype and breeds them. The selected lines are compared after several generations of artificial selection

Estudios de selección artificial. Un cambio significativo en la media fenotípica es inducido durante varias generaciones, en organismos sujetos a una fuerte selección impuesta. El experimentador activamente selecciona a los individuos con el fenotipo extremo y los reproduce. Las líneas seleccionadas se comparan luego de varias generaciones de selección artificial

\begin{tabular}{lll}
\hline Organism & Trait & Reference \\
\hline Fruitfly (Insecta) & Recombination rate & Rice \& Chippindale (2001) \\
Fruitfly (Insecta) & Developmental time and ammonium tolerance & Borash et al. (2000) \\
Chinook salmon (Actinopterygii) & Age at maturity & Quinn et al. (2002) \\
Butterfly (Insecta) & Phenotypic plasticity in wing pigmentation & Wijngaarden et al. (2002) \\
Cricket (Insecta) & Sperm morphology & Morrow \& Gage (2001) \\
Measles virus & Glycoprotein conformation & Woelk et al. (2001) \\
Pyrococcus furiosus (bacteria) & Enzyme activity & Roovers et al. (2001) \\
Sheep (Mammalia) & Sexual performance & Bench et al. (2001) \\
Guppy (Actinopterygii) & Color visual sensibility related to mate recognition & Brooks \& Endler (2001a) \\
Laboratory rat (Mammalia) & Aerobic capacity & Koch \& Britton (2001) \\
Whole microbian ecosystem & Any desired property of the ecosystem & Swenson et al. (2000) \\
Fruitfly (Insecta) & Reverse evolution of life histories & Teotonio \& Rose (2000) \\
Laboratory mouse (Mammalia) & Nest building behavior & Bult \& Lynch (2000) \\
Aphid (Insecta) & Survival rate in a monodiet & Beck \& Toft (2000) \\
Poecilid fish (Actinopterygii) & Heat stress resistance & Baer \& Travis (2000) \\
Fruitfly (Insecta) & Parasitoid resistance & Fellowes et al. (1999) \\
Angiosperm & Proportion of flowering rosetes & Van Kleunen et al. (2002) \\
Laboratory mouse (Mammalia) & Voluntary locomotion & Swallow et al. (1999) \\
Fruitfly (Insecta) & External morphology & Sanchez et al. (1999) \\
\hline & & \\
\hline
\end{tabular}




\section{TABLE 4}

Experimental evolution. Experimental populations are faced with contrasting environments and evolution (character displacement or change in allele frequencies) is demonstrated after several generations (Stearns et al. 2000)

Evolución experimental. Poblaciones experimentales son enfrentadas con ambientes contrastantes y la evolución (desplazamiento de caracteres, o cambio en la frecuencia alélica) se evidencia luego de varias generaciones (Stearns et al. 2000)

\begin{tabular}{|c|c|c|c|}
\hline Organism & Imposed environment & Resulted change & Reference \\
\hline $\begin{array}{l}\text { Escherischia coli } \\
\text { (Bacteria) }\end{array}$ & $\begin{array}{l}\text { Glucose- and maltose- } \\
\text { limited medium }\end{array}$ & Fitness variation & Travisano (1997) \\
\hline Soil bacterium & $\begin{array}{l}\text { Liquid versus } \\
\text { agar medium }\end{array}$ & $\begin{array}{l}\text { Morphological changes } \\
\text { in cell envelope }\end{array}$ & Riley et al. (2001) \\
\hline $\begin{array}{l}\text { Pyrococcus furiosus } \\
\text { (Bacteria) }\end{array}$ & Low temperature & $\begin{array}{l}\text { Enzyme temperature } \\
\text { activity profile }\end{array}$ & Roovers et al. (2001) \\
\hline $\begin{array}{l}\text { Escherischia coli } \\
\text { (Bacteria) }\end{array}$ & Glucose-limited medium & Novel mutations & Schneider et al. (2000) \\
\hline $\begin{array}{l}\text { Ribozyme (catalitic } \\
\text { RNA molecule) }\end{array}$ & Oligonucleotic media & DNA cleavage activity & Hanczyc \& Dorit (2000) \\
\hline Fruitfly (Insecta) & Cadmium rich medium & $\begin{array}{l}\text { Resistance to cadmium } \\
\text { by changes in life histories }\end{array}$ & Shirley \& Sibly (1999) \\
\hline Fruitfly (Insecta) & High adult mortality & $\begin{array}{l}\text { Changes in lifespan, growth, } \\
\text { maturation and reproduction }\end{array}$ & Stearns et al. (2000) \\
\hline $\begin{array}{l}\text { Escherischia coli } \\
\text { (Bacteria) }\end{array}$ & Glucose-limited medium & $\begin{array}{l}\text { Mainteinance of genetic } \\
\text { polymorphisms }\end{array}$ & Rosen \& Lenski (2000) \\
\hline $\begin{array}{l}\text { Escherischia coli } \\
\text { (Bacteria) }\end{array}$ & Cold environment & A cold-adapted protease & Taguchi et al. (1999) \\
\hline Fruitfly (Insecta) & Experimental sympatry & $\begin{array}{l}\text { Reproductive character } \\
\text { displacement in mate recognition }\end{array}$ & Higgie et al. (2000) \\
\hline Apple maggot (Insecta) & $\begin{array}{l}\text { Artificial introduction of } \\
\text { a new population }\end{array}$ & Sympatric speciation in progress & Filchak et al. (2000) \\
\hline Drosophila (Insecta) & Thermally varying cultures & $\begin{array}{l}\text { Polymorphism of a heat-shock } \\
\text { protein }\end{array}$ & Bettencourt et al. (1999) \\
\hline $\begin{array}{l}\text { Escherischia coli } \\
\text { (Bacteria) }\end{array}$ & Thermally varying cultures & Cromosomal changes & Berthorsson \& Ochman (1999) \\
\hline
\end{tabular}

can "choose" evolutionary solutions to some imposed environmental regime. Since not all solutions are available, this approach gives valuable knowledge regarding constraints on evolution. Some notoriuos examples of both artificial selection and experimental evolution include the experimental phenotypic displacement in bristle count of Drosophila (Thoday \& Gibson 1962), the abrupt changes induced by experimental isolation in natural populations of guppies (Reznick et al. 1990, 1997), and the elegant evolution experiments where fitness was clearly determined as a central cause of adaptations in Escherichia coli (Lenski et al. 1991, Leroi et al. 1994, Travisano et al. 1995, see also Tables 3 and 4). Actually, the role of fitness as a real and meaningful (i.e., non-arbitrary) measure of reproductive potential has been tested several times (Sinervo \& Huey 1990, Sinervo et al. 1992, Kruuk et al. 2000, Huey \& Berrigan 2001).

\section{Applied evolution}

The success of natural selection in explaining adaptive change has inspired its use to solve practical problems in a number of disciplines. Classic examples of applied evolution are the use of artificial selection to improve animal and plant production for human consumption (Wood \& Orel 2001). More recently, the use of the tree of life in comparative methods 
permited the tracking of diseases in molecular epidemiology (Bull \& Wichman 2001). Directed evolution, or the manipulation of molecules to evolve (e.g., in vitro replication of nucleic acids) (Wichman et al. 2000) is a common technique thought to produce artificial molecules for medical use, such as the DNA enzyme that cleaves RNA molecules, developed to limit arterial damage from angioplasty (Santoro \& Joyce 1997), or the cold-adapted protease engineered by experimental evolution (Taguchi et al. 1999, Table 4).

One of the best tests of a model is to allow it to work in an artificial or virtual setting, and evolution by natural selection works, as revealed by several artificial systems that were allowed to evolve and produced solutions that could not have been attained if natural selection was not opperating. This is the case of evolutionary computation in artificial inteligence (Freedman 1994). Evolutionary computation is an interesting application that lies completely outside the biological sciences. This approach uses the replication of specific aspects of natural selection to develop programs that solve problems in unexpected ways. Usually, a collection of variant solutions or programs (i.e., the "population") is subjected to selection by imposing some measure of "fitness". The best solutions are selected as "parents" for the next generation, which "reproduce" (with mutation and recombination) to produce a new population that is subjected to selection and so forth (Bull \& Wichman 2001). Although evolutionary computation algorithms can be applied to any computational problem, they are best suited to problems for which there are no other efficient solutions. These evaluation-based algorithms tend to be more robust than user-created programs (Bull \& Wichman 2001).

\section{Is natural drift a novel hypothesis of evolution? The daisyworld parable}

The basic proposal of natural drift is that natural selection is not the main mechanism that explains adaptations. According to Maturana \& Mpdozis (2000), the notion of the environment selecting organisms is misleading since the environment is continuously modified by organisms at the same time. They defend this posture with common-place examples, such as the gas composition of the atmosphere (which is full of oxygen due to photosyntetic organisms) and cases of coevolution where the evolution of one species modifies, and is modified by, the evolutionary change of another species. In these cases, the so-called "drift" of organisms and environment, occurs making impossible to predict evolutionary consequences. Maturana \& Mpodozis (2000) claim that natural selection is a consequence of this drift, being natural drift the ultimate cause of evolution. Hence, natural selection would be an epiphenomenon of evolution. Here, I transcribe their main points: (1) "the history of living systems on Earth is the history of the arising, conservation, and diversification of lineages through reproduction, and not of populations; (2) biological reproduction is a systemic process of conservation of some genetic constitution; (3) a lineage arises in the systemic reproductive conservation of an ontogenic-phenotype/ontogenic-niche relation, and not in the conservation of a particular genotype; (4) although nothing can happen in the life history of a living system that is not permitted by its total genotype, whatever happens in it arises in an epigenetic manner, and it is not possible to properly claim that any feature that arises in the life history of an organism is genetically determined; (5) that is behavior what guides the history of living systems, not genetics."

It is extremely difficult to test this hypothesis with prevalent theories and models for evolution since the writing of Maturana \& Mpodozis (2000) is vague. To give just an example, anyone who wishes to understand the first point would ask what do the authors mean with "lineage", a reasonably doubt since Maturana \& Mpodozis (2000) use a completely redefined vocabulary. Then this person would go to the glossary where the term "lineage" is defined as "a phylogeny defined by the conservation of a particular ontogenetic phenotype/ontogenic niche relation through systemic reproduction". Thus the new definition actually increased the number of unkown terms by two ("ontogenetic phenotype" and "ontogenic niche"). So, we now need to search in the glossary two more terms to understand "lineage", after which new unknown terms appear within each definition. Exponential growth models tell us that if each new search yields, in average, two more new terms, the increase in terminology quickly becomes enormous. Clearly, iterating this process will make any reader to miss the original point, and the hypothesis becomes virtually impossible to understand with precission. Morevoer, the main body of Maturana \& Mpodozis's hypothesis is largely a descriptive-qualitative essay, full of truisms, with few, mostly anecdotal examples. Arguments are written in a self-invented language 
that re-defines several terms and concepts that current botanists, zoologists, paleontologists, systematicists, developmental biologists, microbiologists, geneticists, ecologists and evolutionary biologists already know.

A more conceptual criticism is that Maturana \& Mpodozis (2000) confound temporal and spatial scales with different organizational levels. They rarely confront populations and organisms on an intraspecific level where most natural selection and microevolutionary mechanisms apply, according to the proponents of the modern evolutionary theory (Fisher 1930, Haldane 1932, Lande \& Arnold 1983, Wright 1988). The natural drift hypothesis avoids any quantitative reference to individuals in populations, polymorphisms, intraspecific variability or reproductive success, all of which are fundamental concepts in the genetical theory of natural selection (Fisher 1930), the shifting balance theory (Wright 1988), and the multivariate selection theory (Lande \& Arnold 1983), just to mention a few. The concept of natural drift also is very hard to understand because the wording of Maturana \& Mpodozis (2000) cannot clarify where is the unsolved issue in modern evolutionary theory (see Gallardo 1997 for a detailed criticism of the natural drift).

Besides problems of phraseology, the notion of modification of the environment by organisms is interesting. Unfortunately to Maturana \& Mpodozis (2000), this is not a new concept at all. For example, ecologists have defined "ecosystem engineers" as those organisms that modify drastically their immediate environment through their life processes (Estes \& Palmisano 1974). Developmental system theory, on the other hand, uses the idea that organisms should be seen as constructing their environment (Maynard-Smith 2001). Similarly, the general idea proposed by Maturana \& Mpodozis (2000) -that the mechanism of evolution could operate at different organizational levels (i.e., individual, groups, lineages and species)- has received many throughout analyses (Hamilton 1964, Williams 1966, Lewontin 1970, Maynard-Smith 1982, Nunney 1999, Gould 2002).

As it is, the daisyworld parable of Watson \& Lovelock (1983) seems useful in this context. The daisyworld is a model for evolution that does not involve natural selection; instead it proposes an idea similar to that of natural drift, but with equations. Daisyworld is a hypothetical planet in orbit around a star. The entire planet is composed of two species of daisies, one black and one white.
Since both species could exist and grow within narrow temperature limits, and since black daisies decrease the albedo (i.e., warming up the environment; while white daisies make it colder), there is a feedback between the planet environment and daisy growth. According to Saunders (1994) this model shows how regulation can arise without natural selection. Furthermore, Lansing et al. (1998) developed the so-called "system-dependent selection", a sophistication of the daisyworld parable where changes in the distribution of phenotypes resulting from selection alter an environmental parameter in ways that vis-à-vis, modify selection pressures. Here, the Fundamental Theorem of Natural Selection (see Appendix 1) was included explicitly in the simulation, which caused functional organization at the level of the system as a whole, rather than at the level of the individual organism. Lansing et al. (1998) also provided some real examples of this kind of evolutionary dynamics. However, these authors recognized that this type of dynamics is unusual. As in the case of group selection and evolutionarily stable strategies, these evolutionary dynamics depend on fitness rewards in the long term which are not always, the case (Maynard-Smith 1982, 2001). Natural drift proposes an argument that is similar to the Watson \& Lovelock's (1983) model, but it lacks scientific foundations, predictive power, and a thorough literature review. Last, but not the least, it is important to note that Maturana \& Mpodozis (2000) proposed their hypothesis 17 years after Watson \& Lovelock (1983)! Nonetheless, if arguments of natural drift come similar to those of Watson \& Lovelock's (1983) hypothesis, its predictions should be similar and therefore, open to experimental testing.

\section{Concluding remarks}

It might remain the impression that my commentary was focused from a rather extreme selectionist perspective. However, nothing could be more misleading than to believe in natural selection as the unique cause of evolution (Gould \& Lewontin 1979). Several models coexist with natural selection to explain evolutionary change (e.g., Schlichting \& Pigliucci 1998, Lewontin 2000). Non-adaptive processes are common place in nature. For instance, genetic drift occurs in small populations and is driven by the random fixation of alleles, which in turn could generate nonadvantageous structures (Wright 1988). Genetic correlations, on the other hand, are the genetic 
association among traits due to linkage or pleiotropy, and may produce changes in traits that are not the target of natural selection or even counteract selection if correlations are negative (Lande \& Arnold 1983). Similarly, developmental constraints and epigenetics have been presented as important restrictions to adaptive evolution since the final phenotype is a series of integrated responses of regulatory genes during development (Gould 1989, Schlichting \& Pigliucci 1998). Neutral evolution remarked that a great proportion of mutations are completely neutral (i.e., of no effect on the phenotype) since the actual rate of evolution is two orders of magnitude smaller than that calculated in terms of nucleotide substitutions (Kimura 1968). As Kimura (1968) stressed, if neutral mutations are produced in each generation at a very high rate, then the role of genetic drift in finite populations would be determinant to the genetic structure of populations (and hence, to evolutionary change).

In short, the scientific literature discussed shows that alternative explanations are always welcome to discussion as long as they fit the minimum requirements of any scientific hypothesis (Gould 2002). Does natural drift accomplish them? From the information and discussion presented in this review, I trust the reader will find the answer to this question.

\section{ACKNOWLEDGMENTS}

This review was conducted when I was a postdoctoral associate to Program 1 of the Center for Advanced Studies in Ecology \& Biodiversity (CASEB). I thank Enrico Rezende, Theodore Garland, Francisco Bozinovic, Leonardo Bacigalupe, Marco Lardies, and Diego Bustamante for encouraging the critical thinking that developed this review. The responsibility for opinions, criticisms and assertions stated in this article belong, of course, to the author. Also, I thank Pablo Marquet and Ricardo Guiñez for the first hints of knowledge to study microevolutionary processes in natural populations of animals, during my graduate courses at PUC. I also thank the editor, Luis Ebensperger for his excellent and precise suggestions to the last version of this manuscript, and the helpful comments made by two anonymous reviewers. Finally, I recognize that without the courage and persistence that led Humberto Maturana and Jorge Mpodozis to propose their idea, much of the local debate in evolution have not occurred. As an ex-student of their undergraduate course of Evolution, I thank them for their enthusiasm.

\section{LITERATURE CITED}

ALTERS B \& C NELSON (2002) Teaching evolution in higher education. Evolution 56: 1891-1901.

ANTOLIN MF \& JM HERBERS (2001) Evolution's struggle for existence in America's public schools. Evolution 55: 2379-2388.

ARNOLD SJ (1983) Morphology, performance, and fitness. American Zoologist 23: 347-361.

ARNOLD S (1988) Behavior, energy and fitness. American Zoologist 28: 815-827.

BAER CF \& J TRAVIS (2000) Direct and correlated responses to artificial selection on acute thermal stress tolerance in a livebearing fish. Evolution 54: 238-244.

BALLABENI P \& M RAHIER (2000) A quantitative genetic analysis of leaf beetle larval performance on two natural hosts: including a mixed diet. Journal of Evolutionary Biology 13: 98-106.

BALMFORD A, MJ LEWIS, MD BROOKE, ALR THOMAS \& CN JOHNSON (2000) Experimental analyses of sexual and natural selection on short tails in a polygynous warbler. Proceedings of the Royal Society of London B 267: 1121-1128.

BARBRAUD C (2000) Natural selection on body size traits in a long-lived bird, the snow petrel Pagodroma nivea. Journal of Evolutionary Biology 13: 81-88.

BECK JB \& S TOFT (2000) Artificial selection for aphid tolerance in the polyphagous predator Lepthyphantes tenuis. Journal of Applied Ecology 37: 547-556.

BENCH CJ EO PRICE MR DALLY \& RE BORGWARDT (2001) Artificial selection of rams for sexual performance and its effects on the sexual behavior and fecundity of male and female progeny. Applied Animal Behavior Science 72: 41-50.

BERTHORSSON U \& H OCHMAN (1999) Chromosomal changes during experimental evolution in laboratory populations of Escherichia coli . Journal of Bacteriology 181: 1360-1363.

BETTENCOURT BR ME FEDER \& S CAVICCI (1999) Experimental evolution of Hsp70 expression and thermotolerance in Drosophila melanogaster. Evolution 53: 484-492.

BLANCKENHORN WU (2002) The consistency of quantitative genetic estimates in field and laboratory in the yellow dung fly. Genetica 114: 171-182.

BODIE JR \& RD SEMLITSCH (2000) Size-specific mortality and natural selection in freshwater turtles. Copeia 2000: 732-739.

BORASH DJ, H TEOTONIO, MR ROSE \& LD MUELLER (2000) Density-dependent natural selection in Drosophila: correlations between feeding rate, development time and viability. Journal of Evolutionary Biology 13: 181-187.

BRODIE ED, AJ MOORE \& FJ JANZEN (1995) Visualizing and quantifying natural selection. Trends in Ecology and Evolution 10: 313-318.

BROOKS R \& JA ENDLER (2001a) Female guppies agree to differ: phenotypic and genetic variation in matechoice behavior and the consequences for sexual selection. Evolution 55: 1644-1655.

BROOKS R \& JA ENDLER (2001b) Direct and indirect sexual selection and quantitative genetics of male 
traits in guppies (Poecilia reticulata). Evolution 55: 1002-1015.

BROWN CR \& MB BROWN (2000) Weather-mediated natural selection on arrival time in cliff swallows (Petrochelidon pyrrhonota). Behavioral Ecology and Sociobiology 47: 339-345.

BULL JJ \& HA WICHMAN (2001) Applied evolution. Annual Review on Ecology and Systematics 32: 183-217.

BULT A \& CB LYNCH (2000) Breaking through artificial selection limits of an adaptive behavior in mice and the consequences for correlated responses. Behavior Genetics 30: 193-206.

BUMPUS HC (1899) The elimination of the unfit as illustrated by the introduced sparrow, Passer domesticus. Biological Lectures, Wood Hole Marine Biological Station 6: 209-226.

CALVO M, G RODAS, M VALLEJO, A ESTRUCH, A ARCAS, C JAVIERRE, G VISCOR \& JL VENTURA (2002) Heritability of explosive power and anaerobic capacity in humans. European Journal of Applied Physiology 86: 218-225.

CAMUS PA (1997) Sobre el neodarwinismo y el determinismo estructural en Chile: un comentario al libro "Teoría moderna de la evolución". Revista Chilena de Historia Natural 70: 9-22.

CAMUS PA (2000) Evolution in Chile: natural drift versus natural selection, or the preservation of favoured theories in the struggle for knowledge. Revista Chilena de Historia Natural 73: 215-219.

CARBALLO M, C GARCÍA \& E ROLÁN-ÁLVAREZ (2001) Heritability of shell traits in wild Littorina saxatilis populations: results across a hybrid zone. Journal of Shellfish Research 20: 415-422.

CASWELL H. (1989) Fitness and evolutionary demography. In: Sinauer (eds) Matrix population models: 161-177. First edition. Sinauer Associates, Sunderland, Massachusetts, USA.

CHEN Y, BJ MARSH \& W STEPHEN (2000) Joint effects of natural selection and recombination on gene flow between Drosophila ananassae populations. Genetics 155: 1185-1194.

CONNER JK (2001) How strong is natural selection? Trends in Ecology and Evolution 16: 215-217.

COTTER SC \& K WILSON (2002) Heritability of immune function in the catterpillar Spodoptera littoralis. Heredity 88: 229-234.

DOHM MR, JP HAYES \& T GARLAND (2001) The quantitative genetics of maximal and basal rates of oxygen consumption in mice. Genetics 159: 267-277.

ELLERS J \& CL BOGGS (2002) The evolution of wing color in Colias butterflies: heritability, sex linkage, and population divergence. Evolution 56: 836-840.

ENDLER JA (1986) Natural selection in the wild. Princeton University Press, Princeton, New Jersey, USA. 337 pp.

ESTES JA \& JF PALMISANO (1974) Sea otters: their role in structuring nearshore communities. Science 185: 1058-1060.

FAIRBAIRN DJ \& JP REEVE (2001) Natural selection. In: Fox CW, D Roff \& DJ Fairbairn (eds) Evolutionary ecology: 29-43. First edition. Oxford University Press, Oxford, United Kingdom.

FALCONER DS \& TFC MACKAY (1997) Introduction to quantitative genetics. Longman, Edimburgh, Scottland. $464 \mathrm{pp}$

FELLOWES MDE, AR KRAAIJEVELD \& HCJ GODFRAY (1999) Cross-resistance following artificial selection for increased defense against parasitoids in Drosophila melanogaster. Evolution 53: $966-972$
FELSENSTEIN J (1988) Phylogenies and quantitative characters. Annual Review of Ecology and Systematics 19: 445-471.

FILCHAK KE JB ROETHELE \& JL FEDER (2000) Natural selection and sympatric divergence in the apple maggot Rhagoletis pomonella. Nature 407: 739-742.

FISCHER A (2001) Evolución, el nuevo paradigma: una nueva aproximación a las ciencias sociales. Editorial Universitaria, Santiago, Chile. $171 \mathrm{pp}$

FISHER RA (1930) The genetical theory of natural selection. A complete variorum edition. Oxford University Press, New York, New York, USA. 318 pp.

FOX CW (2000) Natural selection on seed-beetle egg size in nature and the laboratory: variation among environments. Ecology 81: 3029-3035.

FREEDMAN DH (1994) Brainmakers: how scientists are moving beyond computers to create a rival to the human brain. Touchtone Books, New York, USA.

GALLARDO MH (1997) Determinismo estructural: ¿teoría o dogma? Revista Chilena de Historia Natural 70: 315-319.

GALLARDO MH (2001) Evolución... el nuevo paradigma: una nueva aproximación a las ciencias sociales. Revista Chilena de Historia Natural 74: 505-734.

GIBBS AG (1999) Laboratory selection for the comparative physiologist. Journal of Experimental Biology 202: 2709-2718

GOCKEL J, SJW ROBINSON, WJ KENNINGTON, DB GOLDSTEIN \& L PARTRIDGE (2002) Quantitative genetic analysis of natural variation in body size in Drosophila melanogaster. Heredity 89: 145-153.

GOSLER AG \& DGC HARPER (2000) Assessing the heritability of body condition in birds: a challenge exemplified by the great tit Parus major L. (Aves). Biological Journal of the Linnean Society 71: 103-117.

GOULD SJ (1989) A developmental constraint in Cerion, with comments on the definition and interpretation of constraint in evolution. Evolution 43: 516-539.

GOULD SJ \& RC LEWONTIN (1979) The spandrels of San Marco and the Panglossian Paradigm: a critique of the adaptationist programme. Proceedings of the Royal Society of London B 205: 581-598.

GOULD SJ (2002) The structure of evolutionary theory. The Belknap Press of Harvard University Press, Harvard, Massachusetts, USA. 1,433 pp.

GRANT BS (1999) Fine tunning the peppered moth paradigm. Evolution 53: 980-984.

GROSSMAN LI, TR SHMIDT, DE WILDMAN \& M GOODMAN (2001) Molecular evolution of aerobic energy metabolism in primates. Molecular Phylogenetics and Evolution 18: 26-36.

GUBITZ T, RS THORPE \& A MALHOTRA (2000) Phylogeography and natural selection in the Tenerife gecko Tarentola delalandii: testing historical and adaptive hypotheses. Molecular Ecology 9: 1213-1221.

HALDANE JBS (1932) The causes of evolution. Princeton University Press, Princeton, New Jersey, USA. 222 pp.

HAMILTON WD (1964) The genetical evolution of social behaviour, I. Journal of Theoretical Biology 7: 1-16.

HANCZYC MM \& RL DORIT (2000) Replicability and recurrence in the experimental evolution of a group I ribozyme. Molecular Biology and Evolution 17: 1050-1060.

HAYES JP \& CSO O'CONNOR (1999) Natural selection on thermogenic capacity of high-altitude deer mice. Evolution 53: 1280-1287.

HEY J \& RM KLIMAN (2002) Interactions between natural selection, recombination and gene density in the genes of Drosophila. Genetics 160: 595-608. 
HIGGIE M, S CHENOWETH \& MW BLOWS (2000) Natural selection and the reinforcement of mate recognition. Science 290: 519-521.

HOEKSTRA HE, JM HOEKSTRA, D BERRIGAN, SN VIGNIERI, A HOANG, AVS HILL, P BEERLI \& JG KINGSOLVER (2001) Strength and tempo of directional selection in the wild. Proceedings of the National Academy of Science of USA 98: 9157-9160.

HUEY RB \& D BERRIGAN (2001) Temperature, demography, and ecottherm fitness. American Naturalist 158: 204-210.

JUENGER T \& J BERGELSON (2000) The evolution of compensation to herbivory in scarlet gilia, Ipomopsis aggregata: Herbivore-imposed natural selection and the quantitative genetics of tolerance. Evolution 54: 764-777.

JUENGER T, T LENNARTSSON \& J TUOMI (2000) The evolution of tolerance to damage in Gentianella campestris: natural selection and the quantitative genetics of tolerance. Evolutionary Ecology 14: 393-419.

KARINO K \& Y HAIJIMA (2001) Heritability of male secondary sexual traits in feral guppies in Japan. Journal of Ethology 19: 33-37.

KELLER L, A GRANT, BR GRANT \& K PETREN (2001) Heritability of morphological traits in Darwin's finches: misidentified paternity and maternal effects. Heredity 87: 325-336.

KELLY MG \& DA LEVIN (2000) Directional selection on initial flowering date in Phlox drummondii (Polemoniaceae). American Journal of Botany 87: 382-391.

KENTNER EK \& MR MESLER (2000) Evidence for natural selection in a fern hybrid zone. American Journal of Botany 87: 1168-1174.

KENTTAMIES H, NV NORDRUM, UT BRENOE, K SMEDS, KR JOHANNESSEN \& M BAKKEN (2002) Selection for more confident foxes in Finland and Norway: heritability and selection response for confident behaviour in blue foxes (Alopex lagopus). Applied Animal Behavior Science 78: 67-82.

KETTLEWELL HBD (1955) Selection experiments on industrial melanism in the lepidoptera. Heredity 9: 323-342.

KIMURA M (1968) Evolutionary rate at the molecular level. Nature 217: 624-626.

KINGSOLVER JG, HE HOEKSTRA, JM HOEKSTRA, D BERRIGAN, SN VIGNIERI, CE HILL,A HOANG, $P$ GIBERT \& P BEERLI (2001) The strength of phenotypic selection in natural populations. American Naturalist 157: 245-261.

KIRK KM, SP BLOMBERG, DL DUFFY, AC HEATH, IPF OWENS \& NG MARTIN (2001) Natural selection and quantitative genetics of life-history traits in western women: a twin study. Evolution 55: 423-435.

KLEBANOV S, K FLURKEY, TH RODERICK, JR ARCHER, CM ASTLE, J CHEN \& DE HARRISON (2001) Heritability of life span in mice and its implication for direct and indirect selection for longevity. Genetica 110: 209-218.

KOCH LG \& SL BRITTON (2001) Artificial selection for intrinsic aerobic endurance runnning capacity in rats. Physiological Genomics 5: 45-52.

KOHN MH, HJ PELZ \& RK WAYNE (2000) Natural selection mapping of the warfarin-resistance gene. Proceedings of the National Academy of Science of USA 97: 7915 .

KOLLIKER M, MWG BRINKHOF, P HEEB, PS FITZE \& H RICHNER (2000) The quantitative genetic basis of offspring solicitation and parental response in a passerine bird with biparental care. Proceedings of the Royal Society of London B 267: 2127-2132.

KRUUK LEB, TH CLUTTON-BROCK, J SLATE, JM PEMBERTON \& S BROTHERSTONE (2000) Heritability of fitness in a wild mammal population. Proceedings of the National Academy of Science of USA 97: 699-703.

LANDE R \& SJ ARNOLD (1983) The measurement of selection on correlated characters. Evolution 37: 1210-1226.

LANSING JS, JN KREMER \& BB SMUTS (1998) Systemdependent selection, ecological feedback, and the emergence of functional structure in ecosystems. Journal of Theoretical Biology 192: 377-391.

LENSKI RE MR ROSE SC SIMPSON \& SC TADLER (1991) Long term experimental evolution in E. coli I. Adaptation and divergence during 2000 generations. American Naturalist 138: 1315-1341.

LEROI AM AF BENNETT \& RE LENSKI (1994) Temperature acclimation and competitive fitness: an experimental test of the Beneficial Acclimation Assumption. Proceedings of the National Academy of Science of USA 91: 1917-1921.

LEVINS R \& R LEWONTIN (1985) The dialectical biologist. Harvard University Press, Harvard, Massachusetts, USA. 303 pp.

LEWONTIN R (1970) The units of selection. Annual Review of Ecology and Systematics 1: 1-18.

LEWONTIN R (2000) The triple helix. Harvard University Press, Harvard, Massachusetts, USA. 136 pp.

LYNCH M \& B WALSH (1998) Genetics and analysis of quantitative traits. Sinauer Associates, Sunderland, Massachusetts, USA. 980 pp.

MALHOTRA A \& RS THORPE (2000) The dynamics of natural selection and vicariance in the Dominican anole: Patterns of within-island molecular and morphological divergence. Evolution 54: 245-258.

MANRIQUEZ G \& ROTHHAMMER F (1997) Teoría moderna de la evolución. Amphora Editores, Santiago, Chile. 64 pp.

MARONE L, F MILESI, R GONZÁLES, ET MEZQUIDA, J LÓPEZ, DE CASENAVE \& V CUETO (2002) La teoría de evolución por selección natural como premisa de la investigación ecológica. Interciencia 27: 137-142.

MATURANA-ROMESIN R \& J MPODOZIS (1992) Origen de las especies por medio de la deriva natural. O la diversificación de los linajes a través de la conservación y cambio de los fenotipos ontogenéticos. Museo Nacional de Historia Natural, Publicación Ocasional (Chile) 46: 1-48.

MATURANA-ROMESIN R \& J MPODOZIS (2000) The origin of species by means of natural drift. Revista Chilena de Historia Natural 73: 261-310.

MAYNARD-SMITH J (1982) Evolution and the theory of games. Cambridge University Press, Melbourne, Australia. $224 \mathrm{pp}$.

MAYNARD-SMITH J (2001) Reconciling Marx and Darwin. Evolution 55: 1496-1498.

MAYNARD-SMITH J \& GR PRICE (1973) The logic of animal conflict. Nature 246: 15-18

MEDEL R (2000) Assessment of parasite-mediated selection in a host-parasite system in plants. Ecology 81: 1554-1564.

MERILA J, LEB KRUUK \& BC SHELDON (2001a) Natural selection on the genetical component of variance in body condition in a wild bird population. Journal of Evolutionary Biology 14: 918-929.

MERILA J, LEB KRUUK \& BC SHELDON (2001b) Cryptic evolution in a wild bird population. Nature 412: 76-79. 
MERRITT TJS \& JM QUATTRO (2001) Evidence for a period of directional selection following gene duplication in a neurally expressed locus of triosephosphate isomerase. Genetics 159: 689-697.

MICHOD RE (1999) Darwinian dynamics. Princeton University Press, Princeton, New Jersey, USA. 262pp.

MOLLER AP (2001) Heritability of arrival date in a migratory bird. Proceedings of the Royal Society of London B 268: 203-206.

MONTEIRO LR, JAF DINIZ, S DOSREIS \& ED ARAUJO (2002) Geometric estimates of heritability in biological shape. Evolution 56: 563-572.

MORROW EH \& JG GAGE (2001) Artificial selection and heritability of sperm lenght in Gryllus bimaculatus. Heredity 87: 356-362.

MOTTEN AF \& JL STONE (2000) Heritability of stigma position and the effect of stigma-anther separation on outcrossing in a predominantly self-fertilizing weed, Datura stramonium (Solanaceae). American Journal of Botany 87: 339-347.

MUELLER U \& A MAZUR (2001) Evidence of unconstrained directional selection for male tallness. Behavioral Ecology and Sociobiology 50: 302-311.

NESPOLO RF, LD BACIGALUPE \& F BOZINOVIC (2003) Heritability of energetics in a wild mammal, the leaf-eared mouse (Phyllotis darwini). Evolution 57: 1679-1688.

NUNNEY L (1999) Lineage selection: natural selection for long-term benefit. In: Keller L (ed) Levels of selection in evolution: 238-252. First edition. Princeton University Press, Princeton, New Jersey, USA.

PARRA-TABLA V \& SH BULLOCK (2000) Phenotypic natural selection on flower biomass allocation in the tropical tree Ipomoea wolcottiana Rose (Convolvulaceae). Plant Systematics and Evolution 221: 167-177.

PARSONAGE S \& J HUGHES (2002) Natural selection and the distribution of shell colour morphs in three species of Littoraria (Gastropoda: Littorinidae) in Moreton Bay, Queensland. Biological Journal of the Linnean Society 75: 219-232.

PFRENDER ME \& M LYNCH (2000) Quantitative genetic variation in Daphnia: Temporal changes in genetic architecture. Evolution 54: 1502-1509.

PILSON D (2000) Herbivory and natural selection on flowering phenology in wild sunflower, Helianthus annuus. Oecologia 122: 72-82.

POGSON GH (2001) Nucleotide polymorphism and natural selection at the pantophysin (Pan I) locus in the Atlantic cod, Gadus morhua (L.). Genetics 157: 317-330.

PRICE GR (1970) Selection and covariance. Nature 227: $520-521$.

PRICE TD, CR BROWN \& MB BROWN (2000) Evaluation of selection on cliff swallows. Evolution 54: $1824-1827$

PROVINE WB (1985) Adaptation and mechanisms of evolution after Darwin: a study in presistent controversies. In: Hohn D (ed) The Darwinian heritage: 825-866. First edition. Princeton University Press, Princeton, New Jersey, USA.

PULIDO F, P BERTHOLD, G MOHR \& U QUERNER (2001) Heritability of the timing of autumn migration in a natural bird population. Proceedings of the Royal Society of London B 268: 953-959.

QUINN TP, JA PETERSON, VF GALLUCI, WK HERSHBERGER \& EL BRANNON (2002) Artificial selection and environmental change: countervailing factors affecting the timing of spawning by coho and chinook salmon. Transactions of the American Fisheries Society 131: 591-598.
REALE D \& M FESTA-BIANCHET (2000) Massdependent reproductive strategies in wild bighorn ewes: a quantitative genetic approach. Journal of Evolutionary Biology 13: 679-688.

REZNICK DA, H BRYGA \& JA ENDLER (1990) Experimentally induced life-history evolution in a natural population. Nature 346: 357-359.

REZNICK DN, FH SHAW, FH RODD \& RG SHAW (1997) Evaluation of the rate of evolution in natural populations of guppies (Poecilia reticulata). Science 275: 1934-1937.

REZNICK D \& J TRAVIS. (2001) Adaptation. In: Fox CW, DJ Fairbairn \& D Roff (eds) Evolutionary ecology: 44-57. First edition. Oxford University Press, New York, New York, USA.

RICE WR \& AK CHIPPINDALE (2001) Sexual recombination and the power of natural selection. Science 294: 555-559.

RILEY MS, VS COOPER, RE LENSKI, LJ FORNEY \& TL MARSH (2001) Rapid phenotypic change and diversification of a soil bacterium during 1000 generations of experimental evolution. Microbiology-UK 147: 995-1006.

ROBERTSON A (1966) A mathematical model of the culling process in dairy cattle. Animal Production 8: $95-108$.

ROFF D (1997) Evolutionary quantitative genetics. Chapman \& Hall, New York, New York, USA. 493 pp.

ROFF DA \& TA MOUSSEAU (1986) Quantitative genetics and fitness: lessons from Drosophila. Heredity 58: 103-118.

ROFF D \& MJ BRADFORD (2000) A quantitative genetic analysis of phenotypic plasticity of diapause induction in the cricket Allonemobius socius. Heredity 84: 193-200.

ROOVERS H, R SÁNCHEZ, C LEGRAIN \& $\mathrm{N}$ GLANSDORFF (2001) Experimental evolution of enzyme temperature activity profile: selection in vivo and characterization of low-temperatureadapted mutants of Pyrococcus furiosus ornithine carbamoyltransferase. Journal of Bacteriology 183: 1101-1105.

ROSEN DE \& RE LENSKI (2000) Long-term experimental evolution in Escherichia coli. VIII. Dynamics of a balanced polymorphism. American Naturalist 155: 24-35

RYAN PG (2001) Morphological heritability in a hybridbuntins complex: Neospiza at inaccessible island. Condor 103: 429-438.

SACCHERI IJ, RA NICHOLS \& PM BRAKEFIELD (2001) Effects of bottlenecks on quantitative genetic variation in the butterfly Bicyclus anyana. Genetic Research 77: 167-181.

SAGAN C (1979) Broca's brain. Ballantine Publishing Group, New York, New York, USA. 397 pp.

SÁNCHEZ L, MA TORO \& C GARCÍA (1999) Improving the efficiency of artificial selection: more selection pressure with less inbreeding. Genetics 151: 1103-1114.

SANTORO SW \& GF JOYCE (1997) A general purpose RNA-cleaving DNA enzyme. Proceedings of the National Academy of Science of USA 94: 4262-4266.

SAUNDERS PT (1994) Evolution without natural selection: further implications of the Daisyworld parable. Journal of Theoretical Biology 166: 365-373.

SCHLICHTING C \& M PIGLIUCCI (1998) Phenotypic evolution: a reaction norm perspective. Sinauer Associates, Sunderland, Massachusetts, USA. 400 pp.

SCHMIDT KT \& H HOI (2002) Supplemental feeding reduces natural selection in juvenile red deer. Ecography 25: 265-272. 
SCHNEIDER D, E DUPERCHY, E COURSANGE, RE LENSKI \& M BLOT (2000) Long-term experimental evolution in Escherichia coli. IX. Characterization of insertion sequence-mediated mutations and rearrangements. Genetics 156: 477-488.

SHINE R \& S SHETTY (2001) The influence of natural selection and sexual selection on the tails of seasnakes (Laticauda colubrina). Biological Journal of the Linnean Society 74: 121-129.

SHIRLEY MDF \& RM SIBLY (1999) Genetic basis of a between-environment trade-off involving resistance to cadmium in Drosophila melanogaster. Evolution 53: 826-836.

SINERVO B \& RB HUEY (1990) Allometric engineering: an experimental test of the causes of interpopulation differences in performance. Science 248: 1106-1108.

SINERVO B, P DOUGHTY, RB HUEY \& K ZAMUDIO (1992) Allometric engineering: a causal analysis of natural selection on offspring size. Science 258: 1927-1930.

SINERVO B \& K ZAMUDIO (2001) The evolution of alternative reproductive strategies: fitness differential, heritability, and genetic correlation between the sexes. Journal of Heredity 92: 198-205.

STEARNS S, M ACKERMANN, M DOEBELI \& M KAISER (2000) Experimental evolution of aging, growth, and reproduction in fruitflies. Proceedings of the National Academy of Science of USA 28: 3309-3313.

STENSETH NC (1999) The evolutionary synthesis. Science 286: 1490-1491.

STIRLING DG, D REALE \& DA ROFF (2002) Selection, structure and the heritability of behaviour. Journal of Evolutionary Biology 15: 277-289.

SVENSSON E \& B SINERVO (2000) Experimental excursions on adaptive landscapes: density-dependent selection on egg size. Evolution 54: 1396-1403.

SWALLOW JG, P KOTEJA, PA CARTER \& $T$ GARLAND (1999) Artificial selection for increased wheel-running activity in house mice result in decreased body mass at maturity. Journal of Experimental Biology 202: 2513.

SWENSON W, J ARENDT \& DS WILSON (2000) Artificial selection of microbial ecosystems for 3 chloroaniline biodegradation. Environmental Microbiology 2: 564-571

SZEKELY T, JD REYNOLDS \& J FIGUEROLA (2000) Sexual size dimorphism in shorebirds, gulls, and alcids: the influence of sexual and natural selection. Evolution 54: 1404-1413.

TAGUCHI S, A OZAKI, T NONAKA, Y MITSUI \& $\mathrm{H}$ MOMOSE (1999) A cold-adapted protease engineered by experimental evolution system. Journal of Biochemistry 126: 689-693.

TEOTONIO H \& MR ROSE (2000) Variation in the reversibility of evolution. Nature 408: 464-466.

THODAY JM \& JB GIBSON (1962) Isolation by disruptive selection. Nature 193: 1164-1166.

TRAVISANO M, JA MONGOLD, AF BENNETT \& RE LENSKI (1995) Experimental tests of the roles of adaptation, chance, and history in evolution. Science 267: 87-90.

TRAVISANO M (1997) Long-term experimental evolution in Escherichia coli .5. Environmental constraints on adaptation and divergence. Genetics 146: 471-479.
TSUJI JS, RB HUEY, FH VAN BERKUM, T GARLAND \& RG SHAW (1989) Locomotor performance of hatchling fence lizards (Sceloporus occidentalis): quantitative genetics and morphometric correlates. Evolutionary Ecology 3: 240-252.

ULLER T, M OLSSON \& F STAHLBERG (2002) Variation in heritability of tadpole growth: an experimental analysis. Heredity 88: 480-484.

UTEVSKAYA OM \& LA ALTRAMENTOVA (2002) Heritability of reproductive traits in the medicinal leech Hirudo medicinalis L. Russian Journal of Genetics 38: 44-49.

VAN DER JEUD HP \& R MCCLEERY (2002) Effects of spatial autocorrelation, natal philopatry and phenotypic plasticity on the heritability of laying date. Journal of Evolutionary Biology 15: 380-387.

VAN KLEUNEN M, M FISCHER \& B SCHMID (2002) Experimentallife-history evolution: selection on the allocation to sexual reproduction and its plasticity in a clonal plant. Evolutioin 56: 2168-2177.

VRBA ES \& SJ GOULD (1986) The hierarchical expansion of sorting and selection: sorting and selection cannot be equated. Paleobiology 12: 217-228.

WATKINS TB (2001) A quantitative genetic test of adaptive decoupling across metamorphosis for locomotor and life-history traits in the Pacific tree frog, Hyla regilla. Evolution 55: 1668-1677.

WATSON AJ \& JE LOVELOCK (1983) Biological homeostasis of the global environment: the parable of Daisyworld. Tellus 35B: 284-289.

WEBER TP (2000) Biological objects, units of selection and character decomposition. Trends in Ecology and Evolution 15: 304-305.

WEHR P, K MACDONALD, R LINDNER \& G YEUNG (2001) Stabilizing and directional selection on facial paedomorphosis - averageness or juvenilization? Human Nature-An Interdisciplinary Biosocial Perspective 12: 383-402.

WICHMAN HA, LA SCOTT, CD YARBER \& JJ BULL (2000) Experimental evolution recapitulates natural evolution. Philosophical Transactions of the Royal Society of London B 355: 1677-1684.

WIJNGAARDEN PJ, PB KOCH \& PM BRAKEFIELD (2002) Artificial selection on the shape of reaction norms for eyespot size in the butterfly Bicyclus anynana: direct and correlated responses. Journal of Evolutionary Biology 15: 290-300.

WILLIAMS GC (1966) Adaptation and natural selection. Princeton University Press, Princeton, New Jersey, USA. 307 pp.

WOELK CH, L JIN, EC HOLMES \& DWG BROWN (2001) Immune and artificial selection in the haemagglutinin $(\mathrm{H})$ glycoprotein of measles virus. Journal of General Virology 82: 2463-2474.

WOOD RJ \& V OREL (2001) Genetic prehistory in selective breeding: a prelude to Mendel. Oxford University Press, Oxford, United Kingdom. 336 pp.

WRIGHT S (1932) The roles of mutation, inbreeding, crossbreeding and selection in evolution. Proceedings of the Sixth International Congress in Genetics 1: 356-366.

WRIGHT S (1988) Surfaces of selective value revisited. American Naturalist 131: 115-123. 


\section{APPENDIX}

\section{The fundamental theorem of natural selection and the Robertson-Price identity}

El teorema fundamental de la selección natural y la identidad de Robertson-Price

The selection differential, defined as in equn (1) has few practical applications. However, Robertson (1966) and Price (1970) found that there is a general equivalence between $S$ and the covariance between fitness and the trait of interest. From the definition, $S=\mu_{\mathrm{s}}-\mu$, and using the parametric mean, $\mu=\int z p(z) d z$, integrated over the entire range of phenotypic values, with $\mathrm{p}(\mathrm{z})$ being the probability density function of the trait $\mathrm{z}$. Hence, supposing that a fitness function, W(z) exist, the probability density of $\mathrm{z}$ after the selective event, $\mathrm{p}_{\mathrm{s}}(\mathrm{z})$, can be defined as

$\mu_{\mathrm{s}}(\mathrm{z})=\frac{W(z) p(z)}{\int W(z) p(z) d z}$

The denominator of this equation is the average population fitness, $\overline{\mathrm{W}}$ and $\mathrm{w}$ (relative fitness) $=\mathrm{W} / \overline{\mathrm{W}}$. Then, by the definition of the parametric mean,

$\mu_{\mathrm{s}}=\int z p_{s}(z) d z=\int z w(z) p(z) d z$

hence, $\mathrm{S}$ is equal to:

$\mathrm{S}=\int z w(z) p(z) d z-\int z p(z) d z$

By the definition of expectation, $\int z w(z) p(z) d z=E[z w(z)]$. Notice that,

$\bar{w}=E(w)=\int w(z) p(z) d z=\int \frac{W}{\bar{W}}(z) p(z) d z=\frac{1}{\bar{W}} \int W(z) p(z) d z=\bar{W} / \bar{W}=1$

Also, it is possible to express $\mathrm{S}$ in terms of expectations,

$\mathrm{S}=\mathrm{E}[\mathrm{z} w(\mathrm{z})]-\mathrm{E}(\mathrm{z}) \mathrm{E}(\mathrm{w})$

which is equivalent to the covariance between the trait and relative fitness,

$\mathrm{S}=\operatorname{Cov}[\mathrm{z}, \mathrm{w}(\mathrm{z})]$

This is the Robertson-Price Identity (Lynch \& Walsh 1998, pp. 46). This equivalence says, among other things, that the selection differential can be estimated by regressing fitness values and trait values in a random sample of individual from a population.

Now recall the breeders equation in (4), $R=h^{2} S$. This is a general equation for any trait (i.e., $z$ ), such that

$\mathrm{R}(\mathrm{z})=\mathrm{h}^{2}(\mathrm{z}) \mathrm{S}(\mathrm{z})$

Where $\mathrm{h}^{2}(\mathrm{z})=\mathrm{V}_{\mathrm{A}}(\mathrm{z}) / \mathrm{V}_{\mathrm{P}}(\mathrm{z})$.

Then, if the trait of interest is fitness (W), the breeders equation can be expressed as

$\mathrm{R}(\mathrm{W})=\frac{V_{A}(W)}{V_{P}(W)} S(W)$

Recall that $\mathrm{S}=\operatorname{Cov}[\mathrm{z}, \mathrm{w}(\mathrm{z})]$ and $\mathrm{w}=\mathrm{W} / \overline{\mathrm{W}}$, thus

$\mathrm{R}(\mathrm{W})=\frac{V_{A}(W) S(W)}{V_{P}(W)}=\frac{1}{\bar{W}} \frac{V_{A}(W) \operatorname{Cov}(W, W)}{V_{P}(W)}$

Since the covariance between a variable with itself is the variance,

$\mathrm{R}(\mathrm{W})=\frac{1}{\bar{W}} \frac{V_{A}(W) V_{P}(W)}{V_{P}(W)}$

Hence,

$\mathrm{R}(\mathrm{W})=\frac{1}{\bar{W}} V_{A}(W)=V_{A}(w)$

Using the formal notation $\left(\mathrm{R}(\mathrm{W})=\Delta \mathrm{W}\right.$ and $\left.\mathrm{V}_{\mathrm{A}}=\mathrm{s}^{2}\right)$,

$\Delta \mathrm{W}=\mathrm{s}^{2} \mathrm{w}$

In other words, the mean change in fitness in a population is the same as the additive genetic variance in relative fitness at this moment. This is also known as the Fundamental Theorem of Natural Selection (Fisher 1930) and it main consequence is that relative fitness cannot be reduced in a population (since variances are always positive). Given that a great amount of additive genetic variance in fitness would mean strong response to selection, and directional selection reduces variance, the theorem predicts that traits close to fitness will present low additive genetic variance, as is the case with life history traits (Roff 1997, Kruuk et al. 2000). 